\title{
Determination of some significant batch culture conditions affecting acetyl-xylan esterase production by Penicillium notatum NRRL-1249
}

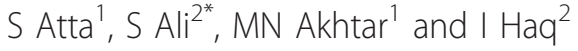

\begin{abstract}
Background: Acetyl-xylan esterase (AXE, EC 3.1.1.72) hydrolyses acetate group from the linear chain of xylopyranose residues bound by $\beta$-1,4-linkage. The enzyme finds commercial applications in bio-bleaching of wood pulp, treating animal feed to increase digestibility, processing food to increase clarification and converting lignocellulosics to feedstock and fuel. In the present study, we report on the production of an extracellular AXE from Penicillium notatum NRRL-1249 by solid state fermentation (SSF).

Results: Wheat bran at a level of $10 \mathrm{~g}$ (with $4 \mathrm{~cm}$ bed height) was optimized as the basal substrate for AXE production. An increase in enzyme activity was observed when $7.5 \mathrm{ml}$ of mineral salt solution (MSS) containing $0.1 \% \mathrm{KH}_{2} \mathrm{PO}_{4}, 0.05 \% \mathrm{KCl}, 0.05 \% \mathrm{MgSO}_{4} .7 \mathrm{H}_{2} \mathrm{O}, 0.3 \% \mathrm{NaNO}_{3}, 0.001 \% \mathrm{FeSO}_{4} .2 \mathrm{H}_{2} \mathrm{O}$ and $0.1 \%(\mathrm{v} / \mathrm{W})$ Tween-80 as an initial moisture content was used. Various nitrogen sources including ammonium sulphate, urea, peptone and yeast extract were compared for enzyme production. Maximal enzyme activity of $760 \mathrm{U} / \mathrm{g}$ was accomplished which was found to be highly significant $(p \leq 0.05)$. A noticeable enhancement in enzyme activity was observed when the process parameters including incubation period $(48 \mathrm{~h})$, initial $\mathrm{pH}(5), 0.2 \%(\mathrm{w} / \mathrm{W})$ urea as nitrogen source and $0.5 \%$ ( $/$ w) Tween-80 as a stimulator were further optimized using a 2-factorial Plackett-Burman design.

Conclusion: From the results it is clear that an overall improvement of more than $35 \%$ in terms of net enzyme activity was achieved compared to previously reported studies. This is perhaps the first report dealing with the use of $P$. notatum for AXE production under batch culture SSF. The Plackett-Burman model terms were found highly significant $(H S)$, suggesting the potential commercial utility of the culture used ( $d f=3, L S D=0.126$ ).
\end{abstract}

\section{Background}

Xylan is the principle component of plant cell wall hemicelluloses. It is a heteroglycan composed of a linear chain of xylopyranose residues bound by $\beta$-1,4-linkage, with a variety of constituents linked to the main chain by glycosidic or ester linkages. The biodegradation of xylan requires a set of esterases and glucanases $[1,2]$. Among these, acetyl-xylan esterase (AXE, EC 3.1.1.72) hydrolyses acetate group from the chain. Together with xylanases, $\beta$-xylosidases, $\alpha$-arabinofuranosidases and $\alpha$ methylglucuronidase, the enzyme is an integral part of the xylanolytic system that is capable of the complete hydrolysis of xylan. It releases methyl residue from cell wall, degrades cellulose, and liberates acetic acid from

\footnotetext{
* Correspondence: alisbiotech@yahoo.com

${ }^{2}$ Institute of Industrial Biotechnology (IIB), GC University Lahore, Pakistan Full list of author information is available at the end of the article
}

$O$-acetyl-galactoglucomannan and $O$-acetyl-4-O-methylglucuronoxylan [3]. Microbial AXE production has been preferred to plant or animal sources because of the easier availability, structural stability and ease to genetic manipulation. It has been purified and characterized from several microorganisms including bacteria and fungi. In particular, filamentous fungi have demonstrated a great capability for secreting a wide range of xylanases, being the genus Aspergillus and Trichoderma the most extensively studied amongst the xylan degrading fungi. However, an important amount of information about the production genetics of these enzymes from the genus Penicillium has accumulated in recent years. A great number of Penicillia are active producers of xylanolytic enzymes, and the use of enzymes from these species has acquired growing importance in biotechnological applications [4]. AXE is a potentially

\section{C) Biomed Central}


useful enzyme in bio-bleaching of wood pulp, treating animal feed to increase digestibility, processing food to increase clarification and converting lignocellulosic substances to feedstock and fuels [5].

Enzyme biosynthesis depends on the type of the strain, composition of medium, and method of cultivation. Various batch culture techniques have been exploited which include liquid culture and solid sate fermentation (SSF). The later holds a tremendous potential for the production of xylanolytic enzymes. It can be of special interest in those processes where crude preparations may be used directly as an enzyme source [6]. In addition, SSF has a number of merits which include non-aseptic conditions, use of a wide variety of matrices, low energy expenditure, less expensive downstream processing, lower wastewater output, potentially higher reproducibility and easier control of contamination [7]. The organisms need essential elements such as carbon, nitrogen, phosphorus and sulphur for growth and subsequent enzyme production. The pattern of accumulated reducing sugar after specific incubation time is characteristic to each microbial species $[3,8]$. The utilization of various agricultural by-products as substrate in industrial processes is gaining momentum under batch culture SSF being carried out aseptically. In the present study, wheat bran was exploited as a substrate for AXE production from Penicillium notatum NRRL-1249. Various nitrogen sources were tested to improve the overall yield of enzyme. The 2-factorial Plackett-Burman experimental design was used to further identify the significant batch culture conditions influencing AXE production.

\section{Methods}

The chemicals including potassium chloride, magnesium sulphate, sodium nitrate, $p$-nitrophenol and $p$-nitrophenyl-acetate were of analytical grade and purchased from Fluka (UK) and Sigma (USA). All other reagents were of the highest possible purity.

\section{Organism and Culture Maintenance}

Penicillium notatum strain NRRL-1249 (initially procured from Northern Regional Research Labs, Peoria, USA) was obtained from IIB Culture Bank. The culture was maintained on malt extract agar (MEA) slopes containing $2 \%$ malt extract, $2 \%$ agar at $\mathrm{pH} 5.6$. The slant cultures were incubated at $30^{\circ} \mathrm{C}$ for $3-5$ days until maximum sporulation. Sub-culturing was carried out every 2 weeks and frequently examined under a light microscope (FE6i, Olympus, Japan) to examine culture purity. The culture was stored at $4^{\circ} \mathrm{C}$ in a cold cabinet (MIR153, Sanyo, Japan).

\section{Inoculum Preparation and Spore Count}

Ten milliliter of sterilized $0.05 \%(\mathrm{w} / \mathrm{v})$ diacetyl ester of sodium sulpho succinic acid (monoxal O.T.) was added to a slant culture of $P$. notatum NRRL-1249 having adequate growth. An inoculating wire-loop was used to disrupt the clumps of spores. The tube was shaken to obtain a uniform homogenous suspension. A haemocytometer was used to count the spore $\left(A_{560 \mathrm{~nm}}=1\right)$ and found to be $1.5 \times 10^{6} \mathrm{CFU} / \mathrm{ml}$.

\section{Fermentation Procedure}

AXE production was carried out aseptically using solid state fermentation (SSF) in $250 \mathrm{ml}$ Erlenmeyer flasks. Ten grams of wheat bran (dry basis) as the substrate with $4 \mathrm{~cm}$ depth was moistened by $10 \mathrm{ml}$ of mineral salt solution (MSS) containing $0.1 \% \mathrm{KH}_{2} \mathrm{PO}_{4}, 0.05 \% \mathrm{KCl}$, $0.05 \% \mathrm{MgSO}_{4} .7 \mathrm{H}_{2} \mathrm{O}, 0.3 \% \mathrm{NaNO}_{3}, 0.001 \% \mathrm{FeSO}_{4} .2 \mathrm{H}_{2} \mathrm{O}$ and $0.1 \%(\mathrm{v} / \mathrm{w})$ Tween-80 $(\mathrm{pH} 5.5)$ at a ratio of $1: 1$ (g:ml). The flasks were cotton plugged and sterilized in an autoclave (KT-40L, ALPCO, Midorigaoka, HamaraShi, Tokyo, Japan) at $103.5 \mathrm{kPa}$. pressure and $121^{\circ} \mathrm{C}$ temperature for $15 \mathrm{~min}$. After sterilization, the medium was allowed to cool at room temperature and seeded with $1 \mathrm{ml}$ of inoculum under aseptic conditions. The inoculum level was maintained during experiments with varying wheat bran mass. The flasks were incubated at $30^{\circ} \mathrm{C}$ for $48 \mathrm{~h}$ and shaken twice daily. All the fermentation experiments were run in a set of three replicates.

\section{Enzyme Extraction}

After the required incubation period, $100 \mathrm{ml}$ of distilled water was added into each of the flasks and agitated at $160 \mathrm{rpm}$ in a rotary shaking incubator at $30^{\circ} \mathrm{C}$ for $1 \mathrm{~h}$. The ingredients of the flasks were filtered and centrifuged at $8000 \times g$ for $15 \mathrm{~min}$.

\section{Analytical Techniques}

The \% constituent of wheat bran was determined using a solid-phase NIR spectrometer (SPQ-1243, Syngene, UK).

\section{Extracellular AXE Assay}

The enzyme activity in the culture supernatant was determined following the modified method of Johnson et al. [9]. One unit of enzyme was defined as the amount of enzyme which releases $1 \mu \mathrm{mol} p$-nitrophenol per minute from $1 \mathrm{~g}$ of substrate under the defined assay conditions. For assay, $5 \mathrm{mM} p$-nitrophenyl-acetate dissolved in dimethyl sulfoxide was used as a substrate. Initially, 0.5 $\mathrm{ml}$ of acetate buffer ( $\mathrm{pH} \mathrm{5.8)}$ and $0.5 \mathrm{ml}$ of the appropriate enzyme dilution were added to the test tubes. To initiate the reaction, $1 \mathrm{ml}$ of substrate was added. The reaction mixture was incubated at $30^{\circ} \mathrm{C}$ for $20 \mathrm{~min}$. 
A blank was also run replacing $0.5 \mathrm{ml}$ of the enzyme dilution with distilled water. $\mathrm{A}_{420 \mathrm{~nm}}$ was determined using a double-beam UV/Vis scanning spectrophotometer (D-21496, Irmeco Gmbh, Heidelberg, Germany). Since the substrate may suffer non-enzymatic deesterification in alkaline $\mathrm{pH}$, assays other than those in $\mathrm{pH}$ dependence studies were carried out at $\mathrm{pH}$ 5.8. The concentration of $p$-nitrophenol was calculated from the standard curve obtained under the assay conditions for enzymatic activity. The enzyme activity was expressed in $\mathrm{U} / \mathrm{g}$.

\section{Optimization of Significant Process Conditions}

The level of wheat bran as a solid substrate was varied from 2.5-15 g and its effect on enzyme activity was studied. Various MSS levels (2.5-15 ml) as initial moisture content were also tested [10]. The $\mathrm{pH}$ of MSS was varied from 4.5 to 7 . The time of incubation was ranged from 12-96 h after inoculation. The effect of nitrogen sources such as ammonium sulphate, urea, peptone and yeast extract was compared. Being optimal, the concentration of urea was varied from 0.1 to $0.6 \%$ (w/w). Later, the effect of Tween-80 (0.25-1.5\%, v/w) on enzyme activity was also investigated [11].

\section{Statistical analysis and application of Plackett-Burman experimental design}

Duncan's multiple range tests (Spss-16, version 9.5) were applied under one-way analysis of variance (IANOVA) and the treatment effects were compared after Snedecor and Cochran [12]. Significance was presented in the form of probability $(p)$ values. The significant batch culture conditions affecting improved AXE productivity were identified using a 2-factorial system i.e., Plackett-Burman experimental design [13]. The variables were denoted at two widely spaced intervals and the effect of individual parameters on enzyme production was calculated by the following equations,

$$
\begin{aligned}
& \mathrm{E}_{\mathrm{O}}=\left(\sum \mathrm{M}_{+}-\mathrm{SM}_{-}-\right) / \mathrm{N} \\
& \mathrm{E}=\beta_{1}+\sum \beta_{2}+\sum \beta_{3}+\beta_{123}
\end{aligned}
$$

In Eq. I, $E_{o}$ is the effect of first parameter under study while $\mathrm{M}+$ and $\mathrm{M}$ - are responses of enzyme production by the fungal strain. $\mathrm{N}$ is the total number of optimizations. In Eq. II, E is the significant parameter, $\beta_{1}$ is the linear coefficient, $\beta_{2}$ the quadratic coefficient while $\beta_{3}$ is the interaction coefficient among significant process parameters.

\section{Results and Discussion}

Various agricultural by-products such as wheat bran, wheat straw, rice bran, rice straw, rice husk and corncobs could be used as substrate for microbial fermentation of both primary and secondary metabolites particularly xylanolytic enzymes [6,7]. The effect of different levels of wheat bran as a substrate was investigated on the production of an extracellular acetyl-xylan esterase by Penicillium notatum NRRL-1249 in solid state fermentation (SSF). An enzyme production of $25 \mathrm{U} / \mathrm{g}$ was obtained when $2.5 \mathrm{~g}$ of wheat bran with $1.2 \mathrm{~cm}$ depth was used (Figure 1). A gradual increase in enzyme production was observed (85-175 U/g) as the level of substrate was further increased from 5-7.5 g. Maximum enzyme production $(270 \mathrm{U} / \mathrm{g})$ was however, achieved with $10 \mathrm{~g}$ of substrate ( $4 \mathrm{~cm}$ bed height). It was due to the fact that optimal level of wheat bran provided an adequate amount of nutrients $(1.32 \%$ proteins, $69 \%$ carbohydrates, $1.9 \%$ fats, $2.6 \%$ fiber, $1.8 \%$ ash content, $0.05 \% \mathrm{Ca}, 0.17 \% \mathrm{Mg}$, $0.35 \% \mathrm{P}, 0.45 \% \mathrm{~K}, 0.12 \% \mathrm{~S}$ and $0.23 \%$ various amino acids) required for the appropriate growth of microorganism. These nutrients were essential for microbial growth and subsequent secretion of xylanolytic enzymes as reported by Park [14]. The enzyme production was declined to $160 \mathrm{U} / \mathrm{g}$ at $15 \mathrm{~g}$ of the substrate $(6.5 \mathrm{~cm}$ depth) possibly due to the thickening of medium or higher bed height, which gave hindrance in the proper aeration. It eventually resulted in the decreased air supply $[4,7]$. The sufficient supply of air is thus highly essential for better growth of mycelial hyphae as well as secretion of enzyme in the fermented mash-culture. Other workers also optimized wheat bran as the basal medium for AXE production [15].

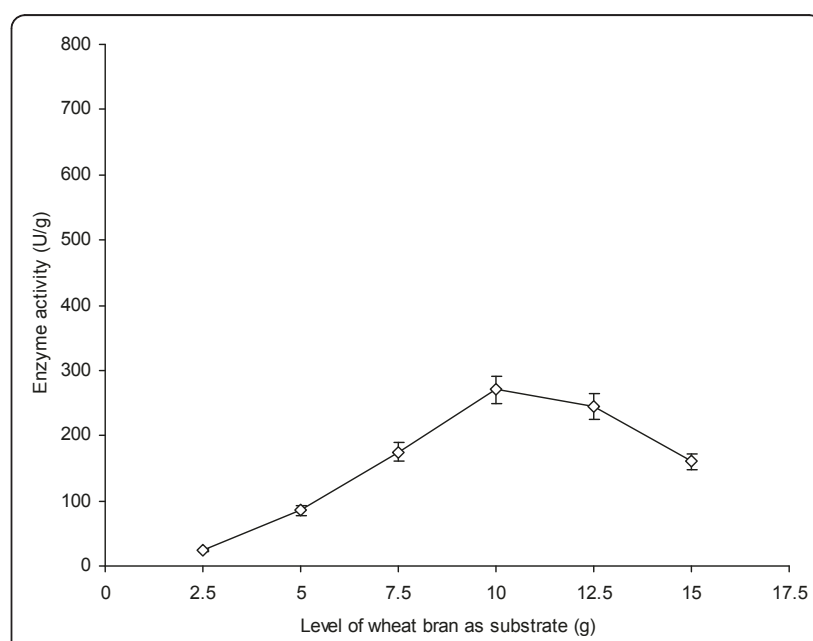

Figure 1 Effect of various levels of wheat bran as a substrate on AXE production from Penicillium notatum NRRL-1249. The substrate was moistened with MSS (pH 5.5) at a ratio of 1:1. The flasks were incubated at $30^{\circ} \mathrm{C}$ for $48 \mathrm{~h}$. Y-bars show the standard deviation ( \pm sd) among the triplicates. 


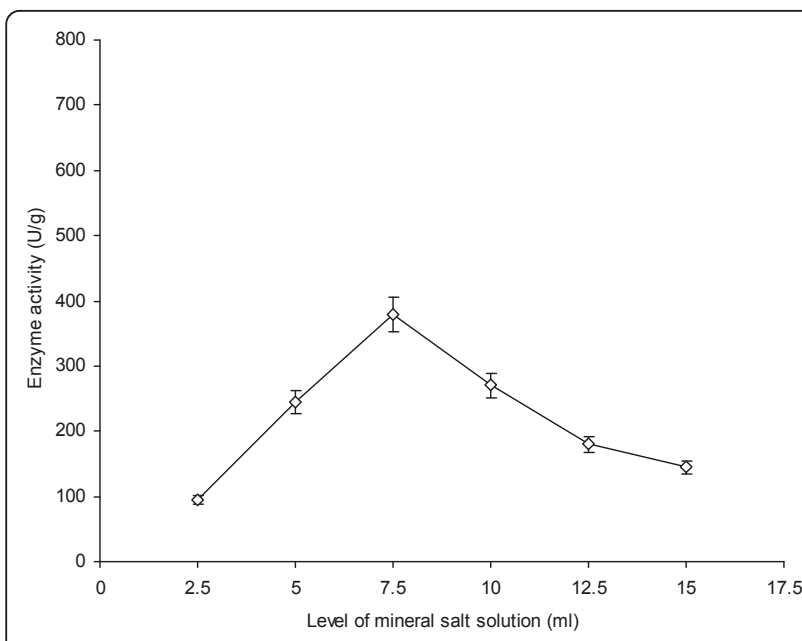

Figure 2 Effect of different levels of mineral salt solution ( $\mathrm{pH}$ 5.5) as initial moisture content on AXE production from $P$. notatum NRRL-1249. Wheat bran (10 g) was used as a basal substrate and incubated at $30^{\circ} \mathrm{C}$ for $48 \mathrm{~h}$. Y-bars show \pm sd among the triplicates.

Initial moisture content has a profound effect on the secretion of metabolites [4]. Various levels of mineral salt solution (MSS, pH 5.5) were used to moisten $10 \mathrm{~g}$ of wheat bran as a solid substrate and their effect on AXE production by $P$. notatum NRRL-1249 was studied (Figure 2). The enzyme production remained almost insignificant from $2.5-5 \mathrm{ml}$ of MSS as there was decreased solubility of nutrients observed which made the nutrients almost unavailable to the fungus causing a decline in its metabolic activity. Similar findings have also been reported by Haltrich et al. [16]. A significant increase $(\mathrm{p} \leq 0.05)$ in the production rate was noticed $(380 \mathrm{U} / \mathrm{g})$ when $7.5 \mathrm{ml}$ of the diluent was used. Beyond the optimal moisture level, enzyme production declined gradually (145 U/g at $15 \mathrm{ml}$ of diluent). A higher level of moisture content is known to affect oxygen diffusion in the substrate which possibly caused water logging of the substrate. Extracellular $\mathrm{pH}$ has a strong influence on enzyme production as a number of microorganisms have a narrow optimal $\mathrm{pH}$ range at which they work progressively. Any deviation from this $\mathrm{pH}$ causes a decline in their enzyme production capability as reported by Linden [17]. The effect of initial $\mathrm{pH}$ on AXE production was also investigated (Figure 3). At $\mathrm{pH}$ 4.5, the enzyme production remained at $250 \mathrm{U} / \mathrm{g}$. Low level of enzyme production at this $\mathrm{pH}$ level showed that the organism did not work well as $\mathrm{pH}$ started moving towards more acidic conditions. The organism was thus found to favor slightly acidic conditions but not sturdy acidic conditions substantiating the findings of Hamlyn et al. [4]. A better yield (384 U/g) was, however noticed when the $\mathrm{pH}$ of MSS was adjusted to 5 . As the $\mathrm{pH}$ was

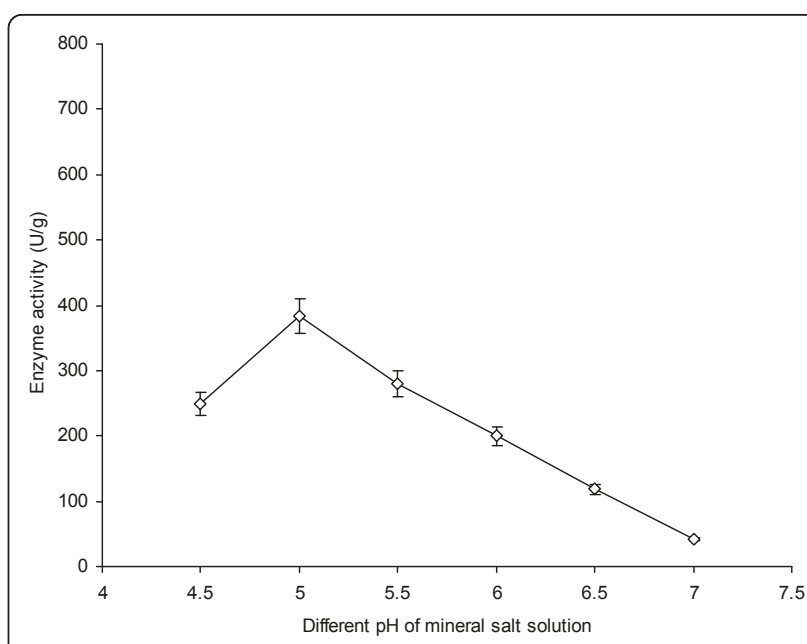

Figure 3 Effect of different $\mathrm{pH}$ of mineral salt solution on AXE production from $P$. notatum NRRL-1249. Wheat bran (10 g) was used as a basal substrate and moistened with MSS at a ratio of 1:0.75. The flasks were incubated at $30^{\circ} \mathrm{C}$ for $48 \mathrm{~h}$. Y-bars show $\pm \mathrm{sd}$ among the triplicates.

increased up to 6, a marked decrease in enzyme production $(200 \mathrm{U} / \mathrm{g})$ was noticed. The $\mathrm{pH}$ optima of 5 have also been investigated for better enzyme production from other fungal cultures such as Aspergillus or Streptomyces spp. [18].

The rate of AXE production from P. notatum NRRL1249 was also undertaken. Initially at $12 \mathrm{~h}$ of incubation, $28 \mathrm{U} / \mathrm{g}$ of enzyme activity was achieved (Figure 4). Enzyme production in the fermented mash increased gradually with the increase in incubation period from 24-36 h. However, the optimal results $(379 \mathrm{U} / \mathrm{g})$ in

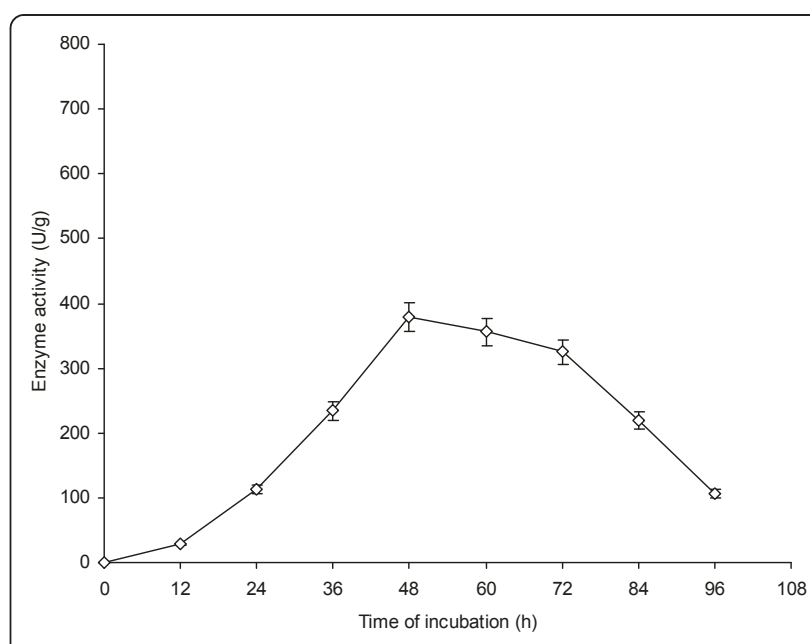

Figure 4 Time of incubation for AXE production from $P$. notatum NRRL-1249. Wheat bran (10 g) was used as a basal substrate and moistened with MSS (pH 5) at a ratio of 1:0.75. The flasks were incubated at $30^{\circ} \mathrm{C}$. Y-bars show \pm sd among the triplicates. 
terms of enzyme production were achieved at an incubation period of $48 \mathrm{~h}$. Afterwards, the enzyme production declined gradually (60-84 h), becoming very low $106 \mathrm{U} / \mathrm{g}$ at $96 \mathrm{~h}$ of incubation. It was due to the decreased amount of available nutrients in the production medium, age of fungi, the presence of inhibitors produced by the culture or depletion of sugar contents as reported by Kansoh and Gammal [19]. Judith and Junior [20] obtained optimal enzyme activity $144 \mathrm{~h}$ after inoculation; therefore present work is economically more significant because reduction in incubation period could reduce the cost of enzyme production. Similar kinds of finding have also been reported previously [21].

In the present study, various nitrogen sources including ammonium sulphate, urea, peptone and yeast extract were compared at a level of $0.2 \%$ for AXE production from $P$. notatum NRRL-1249. The results were compared with the control (having $0.2 \%$ magnesium sulphate). The control gave $388 \mathrm{U} / \mathrm{g}$ of enzyme activity (Figure 5a). The effect of ammonium sulphate on enzyme activity was not found encouraging ( $\mathrm{p} \leq 0.05)$. The enzyme activity was found to be the highest (550 $\mathrm{U} / \mathrm{g}$ ) with urea as a sole nitrogen source. Thus, 1.42 fold better activity was achieved compared to the control. Peptone and yeast extract, however exhibited the least activity i.e., 80 and $47 \mathrm{U} / \mathrm{g}$, respectively. Similar kinds of findings have also been reported by Ximenes et al. [22]. The effect of different levels of urea on the enhanced AXE production was also studied (Figure $5 \mathrm{~b}$ ). The level was varied from 0.1 to $0.6 \%(\mathrm{w} / \mathrm{w})$ for separate trials. At $0.1 \%$ level of urea, enzyme activity was found to be 310 $\mathrm{U} / \mathrm{g}$. However, the maximum enzyme activity $(548 \mathrm{U} / \mathrm{g}$ ) was achieved at $0.2 \%$ of urea as a sole nitrogen source. There was a marked decline in the activity (106-265 U/ g) when higher levels (0.5-0.6\%) were employed. It was due to the fact that higher concentration of free nitrogen caused toxicity which had adverse effects on the development of biomass and enzyme productivity. The work is substantiated with the findings reported earlier $[15,23]$.

Polyoxyethylene sorbitane monooleate (Tween 80) in an appropriate level may have a strong effect on the efficiency of fermentation medium to produce higher level of AXE [9]. The effect of different levels of Tween-80 was investigated on the production of enzyme from $P$. notatum NRRL-1249 (Figure 6). At $0.25 \%$ level of Tween-80, enzyme activity was noted to be $580 \mathrm{U} / \mathrm{g}$. However, the maximum enzyme activity $(760 \mathrm{U} / \mathrm{g})$ was achieved at $0.5 \%$ Tween-80 which was over $35 \%$ improvement in net enzyme activity. It was due to the fact that Tween 80, being a complex source of nutrients, had a strong effect on enzyme synthesizing capability of producer organism [24]. There was a marked decline in the activity when higher levels of Tween- 80 were used

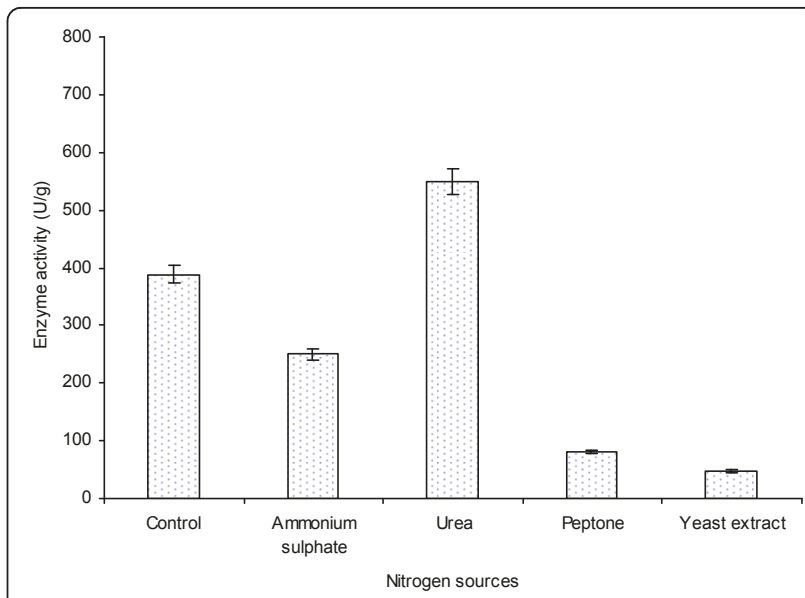

(a)

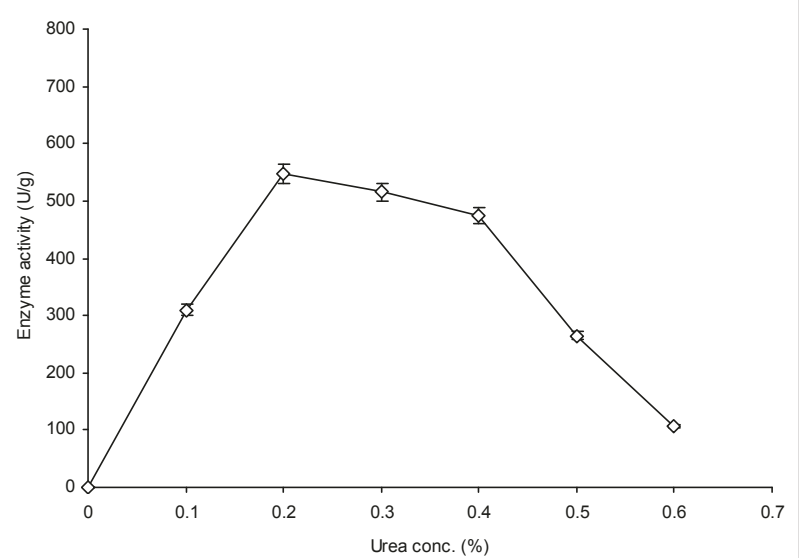

(b)

Figure 5 Evaluation of, a) various nitrogen sources added at a level of $\mathbf{0 . 2 \%}$, and b) urea concentrations on AXE production from $P$. notatum NRRL-1249. Wheat bran (10 g) was used as a basal substrate and moistened with MSS ( $\mathrm{pH}$ 5) at a ratio of 1:0.75. The flasks were incubated at $30^{\circ} \mathrm{C}$ for $48 \mathrm{~h}$. In the control MSS, $0.2 \%$ magnesium sulphate was used as a nitrogen source. Y-bars show \pm sd among the triplicates.

which significantly $(\mathrm{p} \leq 0.05)$ reduced at $1.5 \%$. It was attributed to the over growth of fungal culture and exhaustion of essential minerals from the fermented mash-culture as reported by Belancic et al. [25]; Knob and Carmona [26].

The 2-factorial experimental system i.e., PlackettBurman design was applied to determine the significant process parameters involved in AXE production by P. notatum NRRL-1249 (Table 1). The validation of the model was investigated under the conditions predicted against the responses obtained for enzyme production. A differential correlation was noted between the observed and predicted values as reported by Burkert et al. [27]. The optimal levels of the parameters for improved enzyme production under SSF were incubation period $(48 \mathrm{~h})$, initial $\mathrm{pH}(5), 0.2 \%(\mathrm{w} / \mathrm{w})$ urea as 


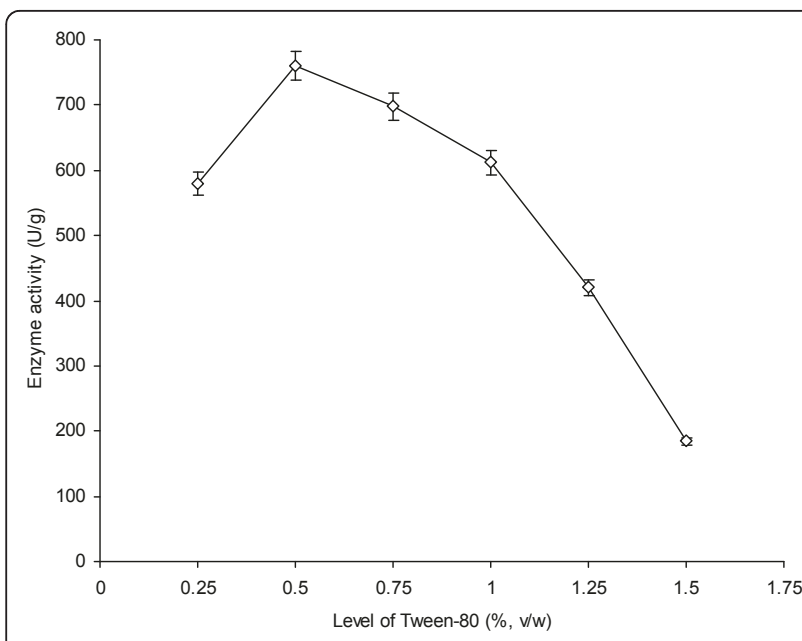

Figure 6 Effect of different levels of Tween-80 on AXE production from $P$. notatum NRRL-1249. Wheat bran $(10 \mathrm{~g})$ was used as a basal substrate and moistened with MSS (pH 5) at a ratio of 1:0.75. The flasks were incubated at $30^{\circ} \mathrm{C}$ for $48 \mathrm{~h}$. Y-bars show \pm sd among the triplicates. Each mean value differ significantly at a level of $p \leq 0.05$.

nitrogen source and $0.5 \%(\mathrm{v} / \mathrm{w})$ Tween-80 as a stimulator. The optimal level of wheat bran as a substrate was found to be $10 \mathrm{~g}$. The statistical analyses of the responses for AXE production were also performed (Table 2). The correlation $(0.122 E+0005)$ of A, B, C and $\mathrm{D}$ for $\mathrm{E}$ values depicted that the model was highly significant ( $\mathrm{p} \leq 0.05$ ). Correspondingly, the lower probability values indicated that the model terms are valid. The analysis of linear, quadratic and interaction coefficients were performed on the batch culture results which highlighted that enzyme production was a function of the independent parameters [13]. The addition of MSS as a diluent (degree of freedom 3) was found necessary for maintaining the possible spatial conformation of enzyme and thus have an important physiological role in the enzyme activity. According to these results, the fungal strain of $P$. notatum NRRL-1249
Table 2 Comparison of statistical analysis of significance level and probability values for AXE production*

\begin{tabular}{lllll}
\hline $\begin{array}{l}\text { Significant } \\
\text { process } \\
\text { parameters }\end{array}$ & $\begin{array}{l}\text { Sum mean } \\
\text { values }\end{array}$ & $\begin{array}{l}\mathbf{F} \text { - } \\
\text { value }\end{array}$ & $\begin{array}{l}\text { Degree of } \\
\text { freedom (df) }\end{array}$ & $\begin{array}{l}\text { Probability } \\
\langle\mathbf{p ~}\rangle\end{array}$ \\
\hline A & 188 & 12.34 & 1 & 0.0874 \\
B & 315 & 25.48 & 1 & 0.0762 \\
C & 446 & 28.15 & 2 & 0.0595 \\
D & 781 & 30.16 & 3 & 0.0238 \\
E & 508 & 22.15 & 2 & 0.0316 \\
Correlation & $0.122 E$ & & & \\
\hline
\end{tabular}

*The letters represent significant process parameters (level of wheat bran, $\mathrm{pH}$ of MSS, incubation period, urea conc. and level of Tween-80) for AXE production. CM - 16.42; $R^{2}-0.128$.

could be considered as an organism of choice for AXE productivity.

\section{Conclusion}

In the present study, Penicillium notatum NRRL-1249 was used for AXE production in solid state fermentation. Wheat bran (10 g) was employed as the basal carbon source with $4 \mathrm{~cm}$ bed height. Mineral salt solution (MSS, $7.5 \mathrm{ml}$ ) containing $0.1 \% \mathrm{KH}_{2} \mathrm{PO}_{4}, 0.05 \% \mathrm{KCl}$, $0.05 \% \mathrm{MgSO}_{4} .7 \mathrm{H}_{2} \mathrm{O}, 0.3 \% \mathrm{NaNO}_{3}, 0.001 \% \mathrm{FeSO}_{4} .2 \mathrm{H}_{2} \mathrm{O}$ and $0.1 \mathrm{ml}$ Tween- 80 at $\mathrm{pH} 5$ as an initial moisture content was also optimized. The most notable finding was the addition of $0.5 \%(\mathrm{v} / \mathrm{w})$ Tween-80 as an enzyme stimulator in the fermented mash-culture which supported a maximal of $760 \mathrm{U} / \mathrm{g}$ enzyme activity. An overall improvement of more than $35 \%$ in terms of enzyme activity was accomplished when the significant process parameters were determined after Plackett-Burman design. The value of AXE correlation (0.122E+0005) depicted that the model terms are highly significant $(H S, \mathrm{p} \leq 0.05)$ indicating commercial utility of the fungal culture $(\mathrm{df}=3, \mathrm{LSD}=0.126)$. However, enzyme characterization is a pre-requisite prior to scale up studies.

Table 1 Application of 2-factorial design at various process parameters for AXE production by P. notatum NRRL-1249*

\begin{tabular}{|c|c|c|c|c|c|c|}
\hline \multicolumn{5}{|c|}{ Process parameters at 2-factorial design } & \multicolumn{2}{|c|}{ AXE production $(\mathrm{U} / \mathrm{g})$} \\
\hline$\overline{\text { Wheat bran }(g)^{A}}$ & MSS $\mathrm{pH}^{\mathrm{B}}$ & Time of incubation $(h)^{c}$ & Urea $(\%, w / w)^{D}$ & Tween-80 $(\%, v / w)^{\mathrm{E}}$ & Observed & Predicted \\
\hline 5 & 4.5 & 24 & na & na & 185 & 198 \\
\hline 7.5 & 4.5 & 36 & na & na & 312 & 385 \\
\hline 10 & 5 & 36 & 0.1 & 0.25 & 455 & 560 \\
\hline 10 & 5 & 48 & 0.2 & 0.5 & 760 & 832 \\
\hline 12.5 & 5.5 & 60 & 0.3 & 0.75 & 646 & 811 \\
\hline
\end{tabular}

*The different letters represent significant process parameters for AXE production. Statistical analysis of the model was based on 2-factorial experimental design. 'na' means that nitrogen source was not added. 


\section{Abbreviations}

SSF: Solid state fermentation; MSS: mineral salt solution; MEA: malt extract agar; NRRL: northern regional research laboratories; U/g: units per gram; rpm: revolutions per minute; $\mathrm{HS}$ : highly significant; $\langle\mathrm{p}\rangle$ : probability of significance level.

\section{Acknowledgements}

We are extremely grateful to the honorable Vice Chancellor for his contributions to promote research culture in the University. Chairperson, Department of Botany is also acknowledged for his support and cooperation.

\section{Author details}

${ }^{1}$ Department of Botany, GC University Lahore, Pakistan. ${ }^{2}$ Institute of Industrial Biotechnology (IIB), GC University Lahore, Pakistan.

\section{Authors' contributions}

SAt and SAI conceived the study and performed the experimental work. MNA and $\mathrm{HI}$ supervised and provided necessary facilities. Authors read and agreed to the final manuscript.

\section{Competing interests}

The authors declare that they have no competing interests.

Received: 21 November 2010 Accepted: 16 May 2011

Published: 16 May 2011

\section{References}

1. Curotto E, Concha M, Campos V, Milagres AMF, Duran N: Production of extracellular xylanases by Penicillium janthinellum. Appl Biochem Biotechnol 1994, 48:107-116.

2. Teng C, Yan Q, Jiang Z, Fan G, Shi B: Production of xylooligosaccharides from the steam explosion liquor of corncobs coupled with enzymatic hydrolysis using a thermostable xylanase. Biores Technol 2010, 101:7679-82.

3. Abdel-Sater MA, El said AHM: Xylan-decomposing fungi and xylanolytic activity in agricultural and industrial wastes. Int Biodeterior Biodegrad 2001, 47:15-21

4. Hamlyn PE, Wales DS, Sagar BF: Extracellular enzymes of Penicillium. In Penicillium and Acremonium. Edited by: Peberdy, J.F. Plenum Press, New York; 1987:245-284.

5. Beg QK, Kapoor M, Mahajan L, Hoondal GS: Microbial xylanases and their industrial applications: a review. Appl Microbiol Biotechnol 2001, 56:326-338.

6. Bakri $Y$, Jacques $P$, Thonart $P$ : Xylanase production by Penicillium canescens 10-10c in solid state fermentation. Appl Biochem Biotechnol 2003, 105:737-748

7. Chavez $R$, Bull P, Eyzaguirre J: The xylanolytic enzyme system from the genus Penicillium. J Biotechnol 2006, 123:413-433.

8. Furniss CSM, Williamson G, Kroon PA: The substrate specificity and susceptibility to wheat inhibitor proteins of Penicillium funiculosum xylanases from a commercial enzyme preparation. J Sci Food Agric 2005 85:574-582.

9. Johnson KG, Fontana JD, MacKenzie CR: Measurement of acetylxylan esterase in Streptomyces. Meth Enzymol 1988, 160:551-560.

10. Andrews SR, Taylor EJ, Pell G, Vincet F, Ducros VM, Davies GJ, Lake JH, Gilbert HJ: The use of forced protein evolution to investigate and improve stability of family 10 xylanases. Biol Chem 2004, 279:54369-54379.

11. Filho EXF: The xylan-degrading enzyme system. Braz J Med Biol Res 1994, 27:1093-1109.

12. Snedecor GW, Cochran WG: Statistical Methods. lowa State University; 7 1980, 32-43.

13. Ahuja SK, Ferreira GM, Morreira AR: Application of Plackett and Burman design and response surface methodology to achieve exponential growth of aggregated shipworm bacterium. Biotechnol Bioeng 2004, 85:666-675.

14. Park YS, Kang SW, Lee JS, Hong SI, Kim SW: Xylanase production in solid state fermentation by Aspergillus niger mutant using statistical experimental designs. Appl Microbiol Biotechnol 2002, 58:761-766.
15. Steiner J, Socha C, Eyzaguirre J: Culture conditions for enhanced cellulase production by a native strain of Penicillium purpurogenum. World $J$ Microbiol Biotechnol 1994, 10:280-284.

16. Haltrich D, Nidetzky B, Kulbe KD, Steiner W, Zupancic S: Production of fungal xylanases. Biores Technol 1996, 58:137-161.

17. Linden J, Meropi S, Stephen D, Ellen J, Michele B, Mlklos P, William A, Michael $\mathrm{H}$ : Purification and characterization of an acetyl esterase from Aspergillus niger. Appl Biochem Biotechnol 2010, 45:383-393.

18. Chungool W, Thongkam W, Raweesri P, Thamchaipenet A Pinphanichakarn P: Production, purification, and characterization of acetyl esterase from Streptomyces sp. PC22 and its action in cooperation with xylanolytic enzymes on xylan degradation. World J Microbiol Biotechnol 2009, 24:549-556.

19. Kansoh AL, Gammal A: Xylanolytic activities of Streptomyces sp. taxonomy production, partial purification and utilization of agricultural wastes. Acta Microbiol Immunol 2002, 48:39-52

20. Judith LSL, Junior NP: Influence of some sugars on xylanase production by Aspergillus awamori in solid state fermentation. Braz Arch Biol Technol 2002, 45:431-437.

21. Polizeli ML, Rizzatti AC, Monti R, Terenzi HF, Jorge JA, Amorim DS: Xylanases from fungi: properties and industrial applications. Microbial Biotechnol 2005, 67:577-91.

22. Ximenes FA, Fonseca AS, Ximenes EA, Silveira FQP, Silva CHC, Lucena SA, Ribeiro WRC, Filho EXF: Xylan-degrading enzyme production by solid state cultures of aerobic fungi. Rev Microbiol 1997, 5:22-28.

23. Seyis I, Aksoz N: Determination of some physiological factors affecting xylanase production from Trichoderma harzianum 1073D3. Microbio 2003, 26:75-81

24. Bajpai P: Microbial xylanolytic enzyme system, properties and applications. Adv Appl Microbiol 1997, 43:141-194.

25. Belancic A, Juan S, Alessandra P, Rene D, Jeannette S, Jaime E: Penicillium purpurogenum produces several xylanases: purification and properties of two enzymes. J Biotechnol 1999, 41:71-79.

26. Knob A, Carmona EC: Xylanase production by Penicillium sclerotiorum and its characterization. App/ Sci J 2008, 4:277-283

27. Burkert JFM, Kalil SJ, Filho FM, Rodrigues MI: Parameters optimization for enzymatic assays using experimental design. Braz J Chem Eng 2006, 23:163-170.

doi:10.1186/1472-6750-11-52

Cite this article as: Atta et al: Determination of some significant batch culture conditions affecting acetyl-xylan esterase production by Penicillium notatum NRRL-1249. BMC Biotechnology 2011 11:52.

\section{Submit your next manuscript to BioMed Central and take full advantage of:}

- Convenient online submission

- Thorough peer review

- No space constraints or color figure charges

- Immediate publication on acceptance

- Inclusion in PubMed, CAS, Scopus and Google Scholar

- Research which is freely available for redistribution

Submit your manuscript at www biomedcentral com/submit
C Biomed Central 